\title{
THE CONFIGURATION OF MASS LAY-OUT AND EXTERNAL SPACE EXPLOITATION OF FISHING VILLAGES \\ STUDY OBJECTS: THE FISHING VILLAGES OF CILINCING AND MARUNDA IN NORTH JAKARTA
}

\author{
${ }^{1}$ Levina. ${ }^{2}$ Dr. Ir. Y. Basuki Dwisusanto, M.Sc. \\ ${ }^{1}$ Student in the Bachelor's (S-1) Study Program in Architecture \\ at Parahyangan Catholic University \\ ${ }^{2}$ Senior lecturer in the Bachelor's (S-1) Study Program in Architecture \\ at Parahyangan Catholic University
}

\begin{abstract}
Cilincing and Marunda are two kampongs situated in the north of Jakarta, immediately bordering on the Java Sea. The existence of the fishing villages sketches the lives of these communities. They make their living out of catching fish and other produce, so the lives of the fishing community take place between water and land. This situation has led to their settlement differing from others in the urban kampong. The synergy stimulated by the water-based context has inspired the unique architectural features of these villages, in terms of planning the lay-out of the dwelling-places or residential area.

This research study is a descriptive-comparative analysis of the exploitation of exterior space based on the configuration pattern of the mass lay-out of the fishing villages observed. The data collection technique consists of gathering the relevant physical data along with those covering related activities. The physical data have been obtained by way of field mapping and observation, while the data concerning activities have been collected through observation and interviews conducted with the respondents, namely the inhabitants of the Cilincing fishing village (RT 012) and of Marunda (RT 03). The data have been divided based on the major outdoor activities of the community involved (sea-faring and residing). Finally, a comparison has been drawn between the research results of these two villages.

The findings indicate that the configuration of the mass lay-out in these two fishing villages has created a quality of exterior space exploitation that is different as well. The one that displays a scattered lay-out pattern has a large volume of exterior space at its disposal that is left unexploited by its inhabitants, both for sea-bound activities and residential land-bound ones. The propinquity of the mass has created exterior space that is more intimate in nature.
\end{abstract}

Keywords: Configuration of mass lay-out, exterior space

\footnotetext{
${ }^{1}$ Corresponding author: levinaripin@gmail.com
} 


\title{
KONFIGURASI TATA MASSA DAN PEMANFAATAN RUANG LUAR KAMPUNG NELAYAN OBJEK STUDI: KAMPUNG NELAYAN CILINCING DAN MARUNDA, JAKARTA UTARA
}

\author{
${ }^{1}$ Levina. ${ }^{2}$ Dr. Ir. Y. Basuki Dwisusanto, M.Sc. \\ ${ }^{1}$ Mahasiswa S1 Program Studi Arsitektur Universitas Katolik Parahyangan. \\ 2 Dosen Pembimbing S1 Program Studi Arsitektur Universitas Katolik Parahyangan.
}

\begin{abstract}
Abstrak- Kampung Nelayan Cilincing dan Marunda adalah dua kampung nelayan yang berada di utara kota Jakarta dan berbatasan langsung dengan Laut Jawa. Keberadaannya kampung nelayan sendiri merupakan gambaran dari kehidupan masyarakat nelayan yang kehidupannya tidak bisa lepas dengan kehidupan air dan darat. Mata pencaharian mereka yang berasal dari tangkapan ikan dan hasil laut lainnya membuat kehidupan nelayan menjadi terpolakan antara air dan darat. Hal ini menjadi fenomena bahwa permukiman nelayan jelas berbeda dengan permukiman kampung kota yang ada di darat. Kesinergian dengan konteks air membuat arsitektur permukiman nelayan memiliki kekhasan dalam tatanan hunian permukiman nelayan. Penelitian yang dilakukan bersifat deskriptif analisis dan komparatif terhadap pemanfaatan ruang luar berdasarkan pola konfigurasi tatanan massa pada kampung nelayan. Teknik pengumpulan data berupa pengumpulan data fisik dan daktivitas. Data fisik didapatkan melalui pemetaan serta observasi lapangan dan data aktivitas didapatkan melalui observasi dan wawancara kepada responden yaitu warga kampung nelayan Cilincing RT012 dan Marunda RT03. Data aktivitas dibagi berdasarkan aktivitas mayor masyarakat (melaut dan bermukim) yang dilakukan pada ruang luar. Kemudian diakhiri dengan melakukan komparasi hasil penelitian dari kedua kampung nelayan tersebut. Berdasarkan penelitian ini maka didapatkan temuan bahwa konfigurasi tatanan massa dari dua kampung nelayan yang berbeda menciptakan kualitas pemanfaatan ruang luar yang berbeda juga. Kampung nelayan yang memiliki tatanan menyebar banyak memiliki ruang luar yang tidak dimanfaatkan warga baik untuk aktivitas melaut ataupun bermukim. Kedekatan antar massa menciptakan ruang luar yang bersifat lebih intim
\end{abstract}

Kata Kunci: Konfigurasi tatanan massa, Ruang luar.

\section{PENDAHULUAN}

Kampung nelayan merupakan permukiman identik dengan komunitas masyarakat yang berprofesi sebagai nelayan. Mata pencaharian mereka berasal dari tangkapan ikan dan hasil laut lainnya, hal ini membuat kehidupan nelayan menjadi terpolakan antara air dan darat. Masyarakat nelayan bermukim di daerah yang tersentuh air dan darat (daerah tepian air). Sehingga perancangan arsitektur permukiman nelayan perlu memperhatikan siklus kehidupan nelayan tersebut.

Massa dan ruang mejadi dua hal penting dalam perancangan arsitektur. Pada perkampungan nelayan, masa- masa bangunan menjadi pembentuk ruang- ruang luar yang menjadi tempat masyarakat melakukan aktivitas dan interaksi sosial. Kesinergian dengan konteks air membuat arsitektur permukiman nelayan memiliki kekhasan dalam tatanan hunian permukiman nelayan. Seperti permukiman nelayan Cilincing dan Marunda yang merupakan permukiman nelayan tradisional tepi laut (disebut juga kampung nelayan).

Fenomena yang yang timbul saat ini adalah pemukiman nelayan di kawasan Cilincing dan Marunda memiliki kesamaan letak geofgrafis, namun memiliki pola tata massa yang berbeda yang menjadi sumber terbentuknya ruang luar pada kedua kampung nelayan tersebut. Hal ini menyebabkan perbedaan dalam pemanfaatan ruang luar sebagai wadah bagi masayarakat melakukan interaksi sosial dan aktivitas keseharian mereka. Dalam kaitannya dengan kehidupan sehari-hari masyarakat nelayan membutuhkan ruang- ruang yang dapat 
menampung aktivitas keseharian mereka, baik di lingkungan rumah dan pekarangannya, ruang luar yang fungsional (interaksi sosial) maupun ruang luar yang produktif. Pemanfaatan ruang terbuka menjadi hal yang penting baik berfungsi ekologis, interaksi sosial, maupun kegiatan ekonomi dan estetika.

Isu permasalahan yang ada adalah pemanfaatan ruang luar pada kampung nelayan berdasarkan bentuk orientasi bangunan. Sehingga dari isu permasalahan tersebut dapat dijabarkan melalui pertanyaan studi sebagai berikut:

(1) Bagaimana bentuk konfigurasi tata massa dan pemanfaatan ruang luar pada kampung nelayan Cilincing?

(2) Bagaimana bentuk konfigurasi tata massa dan pemanfaatan ruang luar pada kampung nelayan Marunda?

(3) Bagaimana bentuk keterkaitan antara pola tata massa kampung nelayan terhadap pemanfaatan ruang luar oleh masyarakat nelayan? Tujuan dari penelitian ini adalah untuk:

(1) Mengetahui pola tata massa dan pemanfaatan ruang luar oleh masyarakat kampung nelayan Cilincing.

(2) Mengetahui pola tata massa dan pemanfaatan ruang luar oleh masyarakat kampung nelayan Marunda.

(3) Mengetahui keterkaitan antara bentuk tata massa terhadap pemanfaatan ruang luar pada kampung nelayan Cilincing dan Marunda

Penelitian ini menjadi penting untuk dilakukan karena fenomena yang diangkat telah lama diperbincangkan dan belum adanya penelitian yang menitikberatkan pada relasi tata massa dengan pemanfaatan ruang luar pada kedua kampung nelayan Adapun manfaat skripsi ini:

(1) Memberikan informasi mengenai konfigurasi tata massa dan pemafaatan ruang luar pada kampung nelayan Cilincing.

(2) Memberikan informasi mengenai konfigurasi tata massa dan pemafaatan ruang luar pada kampung nelayan Marunda.

(3) Memberikan informasi mengenai seberapa besar keterkaitan tata massa terhadap pemanfaatan ruang luar sebagai wadah aktifitas masyarakat nelayan pada kampung nelayan Cilincing dan Marunda

\section{KAJIAN TEORI}

\subsection{METODOLOGI PENELITIAN}

Penelitian yang dilakukan bersifat deskriptif analisis dan komparatif terhadap pemanfaatan ruang luar berdasarkan pola orientasi tatanan massa pada kampung nelayan Cilincing dan Marunda. Jenis penelitian ini merupakan jenis penelitian yang mengungkapkan fakta yang terjadi dilapangan dan terjadi saat penelitian berjalan. Proses kesimpulan diambil dengan cara menjabarkan secara apa adanya fenomena yang diangkat mencakup deskripsi dalam konteks yang mendetail. Tempat penelitian dilakukan pada objek yang diteliti yaitu Kampung Nelayan Cilincing RT12 dan Kampung Nelayan Marunda RT03, kecamatan Cilincing, Jakarta Utara.

Sumber data pada penilitian ini terbagi menjadi dua data utama, yaitu data fisik dan data aktivitas. Data fisik didapatkan melalui pemetaan dan penggambaran kembali konfigurasi tata massa fisik pada peta dasar yang telah dibuat sebelumnya. Sedangakan data aktivitas merupakan data yang didapatkan melalui pemetaan aktivitas warga pada ruang luar dan 
wawancara kepada warga kampung nelayan Cilincing RT12 dan kampung nelayan Marunda RT03.

Pendekatan analisa menggunakan teori Figure Ground untuk mengetahui pola tata massa masing-masing objek penelitian. Kemudian data aktivitas diperoleh melalui pengamatan aktivitas utama warga kampung nelayan yang memiliki persamaan yaitu aktivitas melaut dan bermukim. Aktivitas yang diamati hanya aktivitas yang memanfaatkan ruang luar kampung.

\section{ANALISIS}

\subsection{KETERKAITAN KONFIGURASI TATA MASSA DAN AKTIVITAS RUANG LUAR PADA KAMPUNG NELAYAN}

Kampung nelayan merupakan permukiman yang berada di pesisir pantai dan menjadi permukiman masyarakat yang memiliki mata pencaharian utama sebagai nelayan. Menurut UU no 27 tahun 2007, wilayan pesisir adalah daerah peralihan ekosistem darat dan laut yang dipengaruhi oleh perubahan di darat dan laut. Aktivitas pada wilayah pesisir sebagian besar masih didominasi oleh aktivitas darat (dilakukan di wilayah perairan) serta aktivitas marin (dilakukan di wilayah daratan). Sehingga dapat dikatakan bahwa kedua daerah tersebut memiliki keterkaitan satu sama lain atau saling mempengaruhi.

Karakteristik permukiman nelayan yang ada di wilayah pesisir adalah, rumah- rumah cenderung menghadap ke jalan- jalan utama dan gang- gang sempit, jalan-jalan dan gang-gang sempit berubah menjadi halaman rumah, jarak antar rumah saling berhimpitan satu sama lain, rumah-rumah yang didirikan di pinggir jalan utama rata-rata memiliki kondisi cukup baik (Kusnadi (2003).

Teori Rapoport (1977), bahwa terdapat tiga macam orientasi permukiman yaitu: (1) permukiman mengelilingi central space, (2) orientasi permukiman menyusuri jalan/along the streets. Ada dua macam organisasi dalam orientasi permukiman tersebut, yaitu rumah berada di sepanjang jalan dan berseberangan dengan rumah lain atau rumah berada disepanjang jalan dan berseberangan dengan unsur air (waterfront), (3) Orientasi ke arah dalam (inside-out). Orientasi ini memiliki domain privat-publik. 


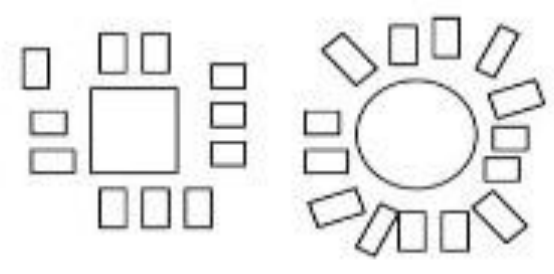

Permukiman yang mengelilingi suatu pusat

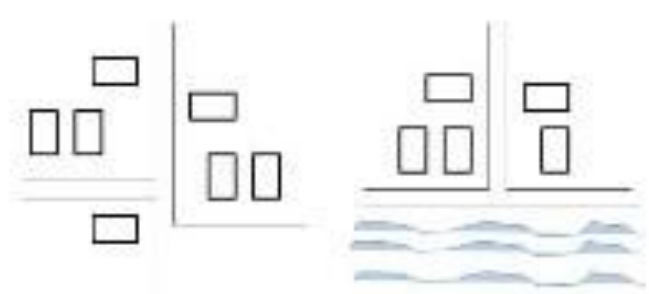

Jalan yang saling berhubungan (kiri) dan rumah di tepian air kanan)

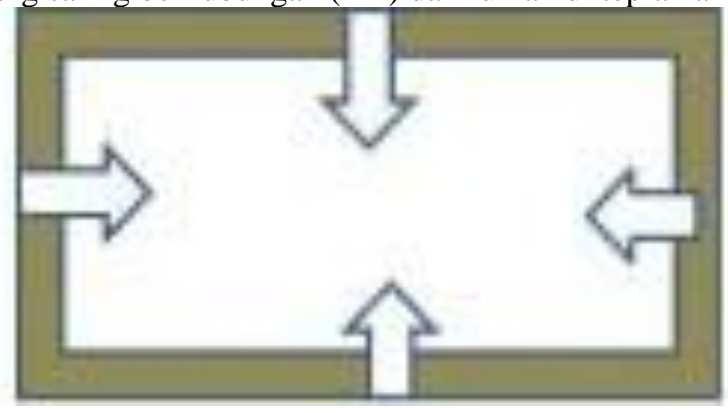

Orientasi kearah dalam (inside-out).

Figur 1. Karakter Permukiman Dilihat Dari Organisasi Ruang Permukiman (Rapoport,1977)

Menurut Fernandez (2011), terdapat beberapa tipe pola sirkulasi pada permukiman, antara lain:

(1) Garis grid teratur

Suatu permukiman dengan jalan-jalan paralel dan transversal dimensi yang hampir seragam, dalam bentuk grid atau kotak-kotak, yang terletak di daerah yang datar. Pola seperti ini banyak ditemui pada dataran Amerika Latin, terlihat pada Figur 2. 


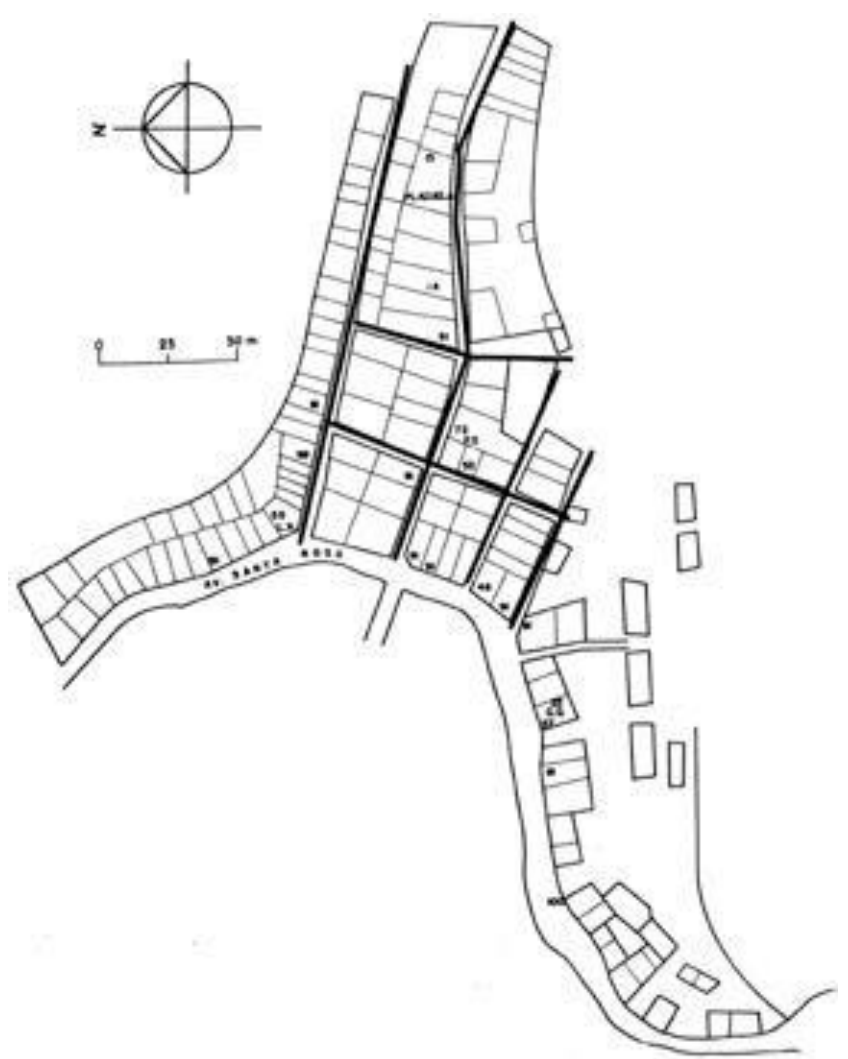

Figur 2. Permukiman Kumuh Santa Rosa, Lima - Peru Sumber: Fernandez, 2011

(2) Garis grid tidak teratur

Konfigurasi fisik danspasial bentuk grid yang tidak beraturan ini sering dijumpai pada lahan yang berbatu dan juga tanah datar. Pada pola ini terlihat pola grid yang nyata namun tidak beraturan arah. (Figur 3)

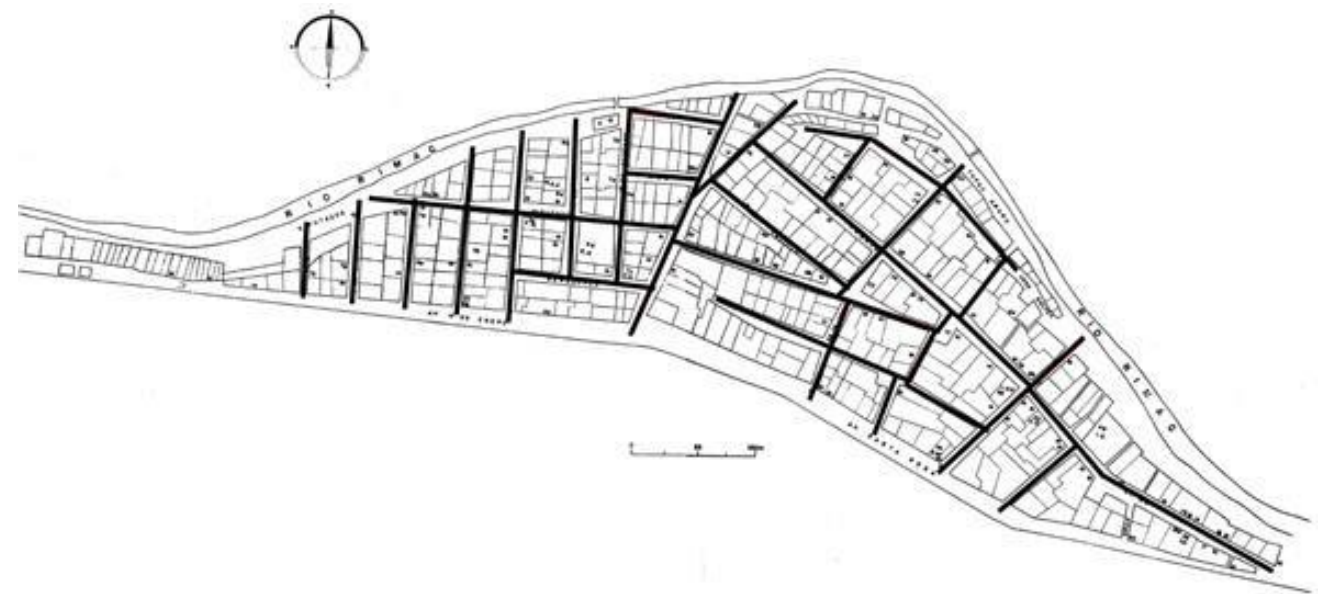

Figur 3. Permukiman Kumuh Dos de Mayo, Lima - Peru

Sumber: Fernandez, 2011

(3) Pola yang disesuaikan dengan topografi lahan

Suatu permukiman kumuh yang menyesuaikan dengan kondisi topografi lahannya, dimana jalur sirkulasi berkembang tanpa adanya perencanaan. Jalan dan koridor yang terbentuk berdasarkan kebutuhan penduduk setempat. Merupakan jalur sirkulasi yang sempit 
dan berliku-liku membentuk jaringan yang kompleks yang timbul di antara dinding-dinding rumah. (Figur 4)

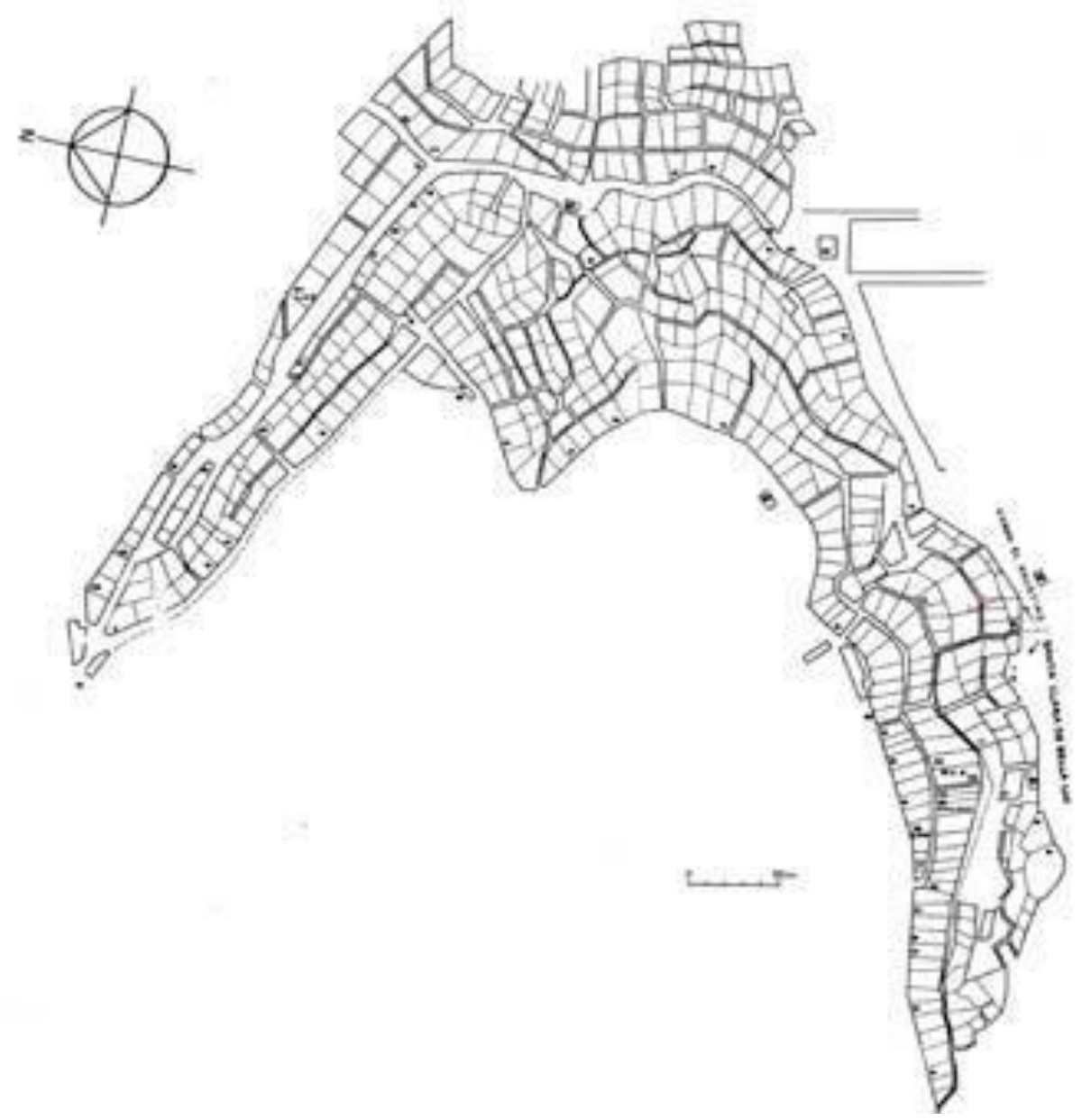

Figur 4. Permukiman Kumuh Cerro El Agustino, Lima - Peru

Sumber: Fernandez, 2011 meliputi:

Pola-pola kawasan secara tekstural dapat diklasifikasikan menjadi tiga kelompok, yang

(1) Homogen, adalah susunan kawasan yang bersifat sejenis dimana hanya ada satu pola penataan.

(2) Heterogen, susunan kawasan yang bersifat beberapa jenis dimana ada dua atau lebih pola berbenturan, sebagai contoh adalah dua buah kawasan di Kota Aachen, Jerman. Kedua kawasan tersebut memiliki pola yang bersifat heterogen.

(3) Menyebar, susunan kawasan yang bersifat menyebar dan kecenderungan kacau. Sebagai contoh adalah kawasan pada Kota Bonn dan Hamburg, Jerman. Kedua kawasan ini memiliki pola yang bersifat berantakan atau kacau.

Figure ground didasarkan atas dua komponen utama, yaitu:

(1) Solid (figure) merupakan blok-blok dari massa bangunan (building mass) berupa elemen masif (bangunan) berfungsi sebagai wadah kegiatan manusia.

(2) Void (ground) merupakan ruang luar berupa ruang terbuka (open space) 


\subsection{GAMBARAN UMUM KAMPUNG NELAYAN \\ 3.2.1 KAMPUNG NELAYAN CILINCING}

Kawasan Cilincing terletak di sebelah timur Pelabuhan Tanjung Priok, Kecamatan Cilincing, termasuk wilayah Kotamadya Jakarta Utara. Kampung nelayan cilincing berada di atas daratan yang terbentuk dari tumpukan sampah kulit kerang bercampur pasir. Secara geografis, berada rata-rata $50 \mathrm{~cm}$ di atas permukaan laut, dengan jenis tanah empang dan rawa yang cukup dalam.

Sebagian besar massa bangunan yang ada adalah rumah warga. Rumah- rumah tersebut sudah dibangun menggunakan material bata, namun masih terdapat rumah yang hanya terbuat dari bambu dan kayu. Rumah- rumah tersebut pada umumnya bertingkat satu.

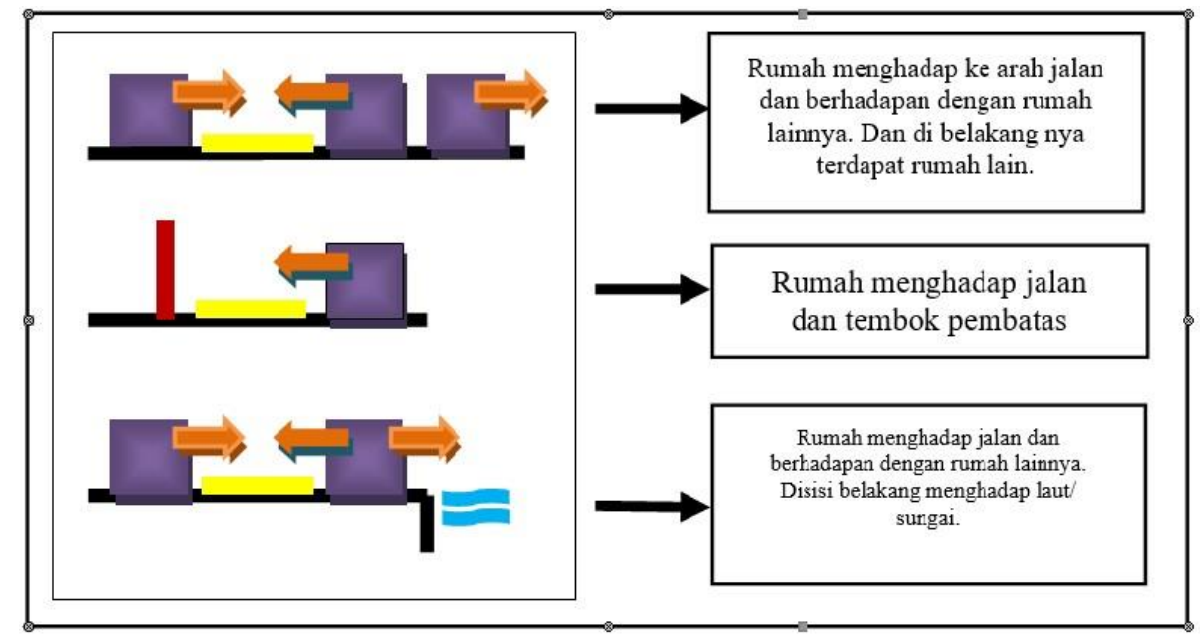

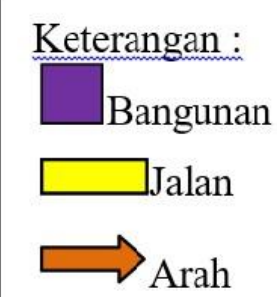

Hadap

Bangunan

Figur 5. Tata massa bangunan pada kampung yang membentuk ruang jalan

\subsubsection{KAMPUNG NELAYAN MARUNDA}

Marunda adalah kelurahan di kecamatan Cilincing, Jakarta Utara, Indonesia. Kondisi sebagian kampung yang berwujud empang-empang, menyulitkan akses transportasi. Letaknya di pinggir pantai, sehingga sebagian besar penduduknya bermata pencaharian sebagai nelayan. Kampung nelayan marunda RT03 memiliki luas lahan sebesar 6 ha terdiri atas 118 kepala keluarga dengan total 334 jiwa penduduk yang menghuni 70 rumah. kampung nelayan tersebut berdiri diatas tanah milik orang lain (bukan pemerintah),

Tata massa pada kampung nelayan Marunda cenderung menyebar dan tidak beraturan. Rumah- rumah tidak saling berhadapan satu sama lain. sebagian besar rumah yang ada di kampung nelayan Marunda menghadap ke arah laut, empang, atau pun jalanan. Sehingga kampung tidak memiliki banyak jalan sempit yang biasanya menjadi tempat area berkumpul untuk melakukan interaksi sosial.

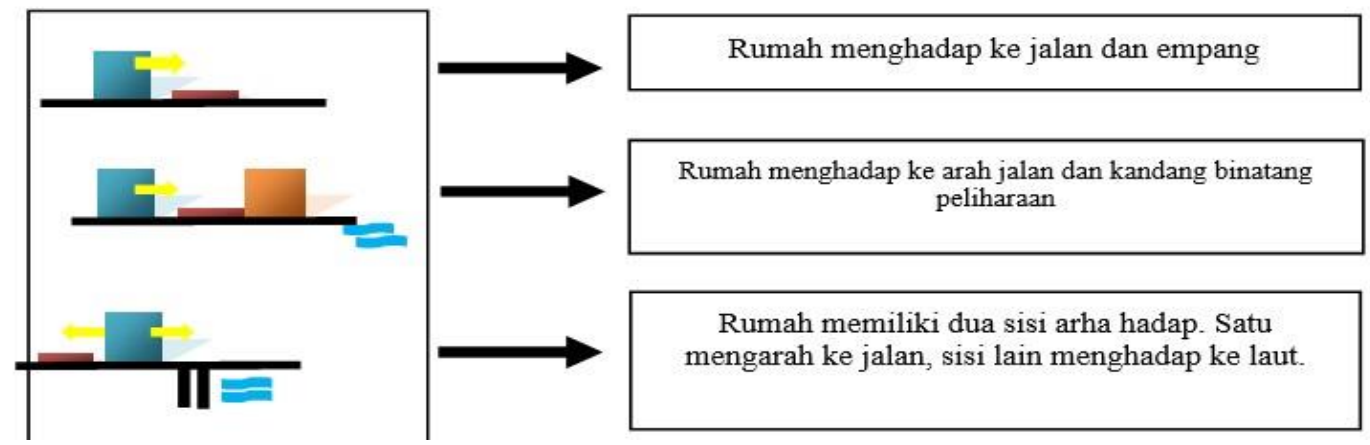

Figur 6. Bentuk- bentuk arah hadap dan orientasi massa bangunan Kampung nelayan Marunda 


\subsection{RELASI KONFIGURASI TATA MASSA DAN PEMANFAATAN RUANG LUAR PADA KAMPUNG NELAYAN}

\subsubsection{KAMPUNG NELAYAN CILLINCING}

Merupakan salah satu permukiman nelayan yang terbentuk secara informal. Para nelayan membangun rumah mereka di tepi laut dengan maksud agar memudahkan mereka untuk bekerja sehingga menghemat waktu perjalanan dan biaya transportasi. Sehingga kampung nelayan memiliki pola sirkulasi garis grid teratur (Fernandez,2011). Kampung memiliki jalan- jalan pararel dengan dimensi yang hampir seragam, dalam bentuk grid, dan terletak di daerah yang datar. Rumah - rumah tersebut semakin lama semakin bertambah banyak dan membentuk suatu kawasan yang dikenal sebagai kampung. Tidak hanya rumah, bangunan yang terbangun pada kampung nelayan Cilincing antara lain Tempat Pelelangan Ikan (pasar ikan), PAUD, Mushola, dan warung- warung.

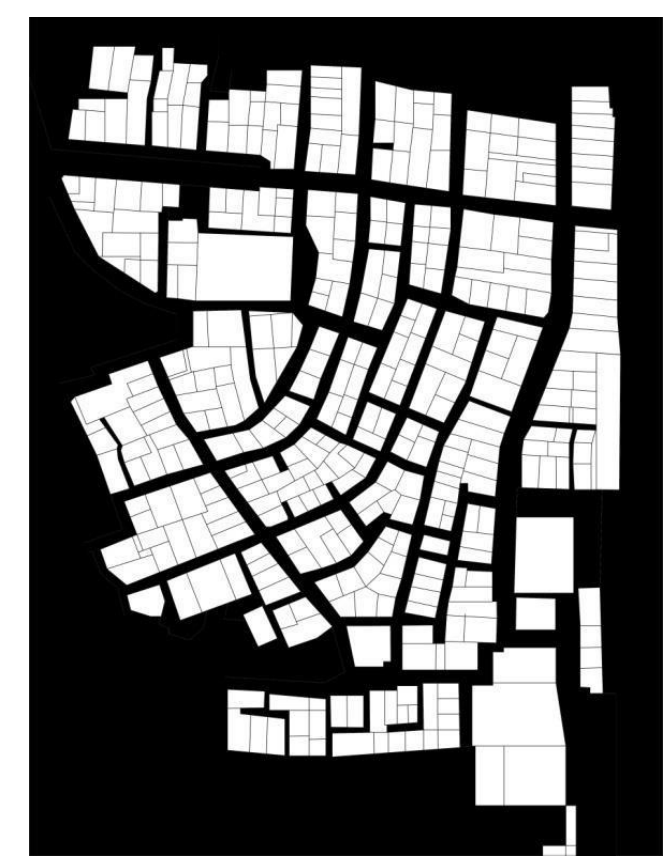

Figur 7. Figure Ground Kampung nelayan Cilincing

Kawasan kampung nelayan Cilincing dapat di golongkan ke dalam kawasan yang bersifat homogeny. Kecenderungan massa di tata secara linier yang berderet dan berhimpit satu sama lainnya. Tata massa pada kampung nelayan Cilincing membentuk beberapa massa (solid) dan ruang terbuka (void) pada kawasan kampung yang diantaranya adalah, Massa (solid) pada kawasan kampung yang diantaranya adalah,

\section{(1) Rumah}

Berdasarkan teori Rapoport (1977), kampung nelayan Cilincing tergolong kedalam tatanan kampung yang memiliki orientasi permukiman ke arah dalam (inside-out). Orientasi ini memiliki ruang- ruang yang bersifat privat-publik. Ruang- ruang yang bersifat publik termasuk ke dalam ruang- ruang yang digunakan untuk aktivitas utama masyarakat nelayan. Pada umumnya rumah- rumah pada kampung nelayan Cilincig menghadap ke jalan sebagai jalur sirkulasi. Terdapat beberapa varian arah hadap rumah, diantaranya: 


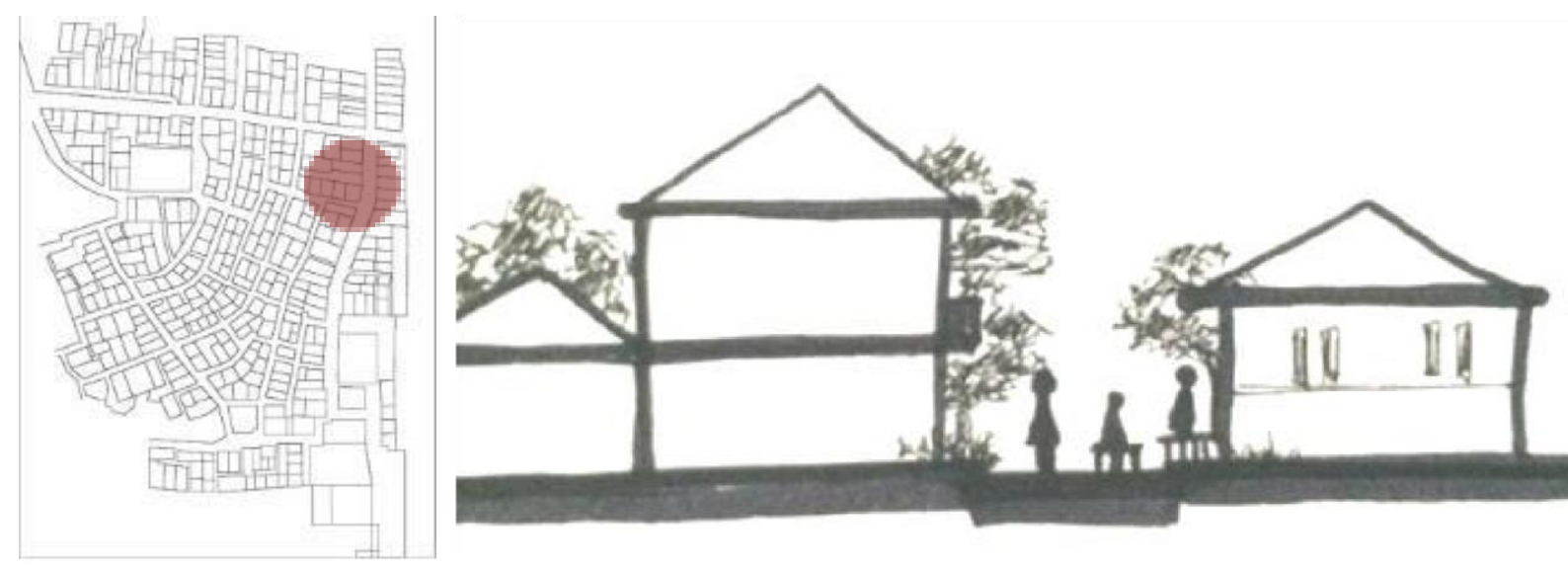

Figur 8: Sketsa potongan permukiman warga yang saling berhadap- hadapan
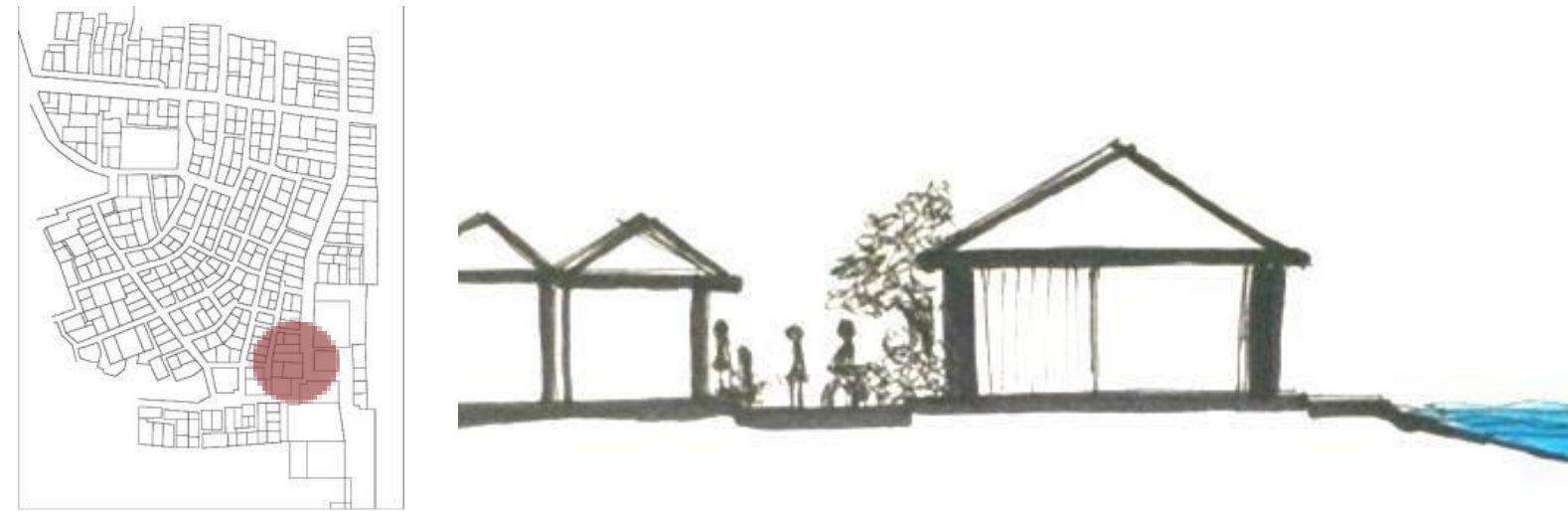

Figur 9. Sketsa potongan permukiman warga yang berhadapan dengan TPI
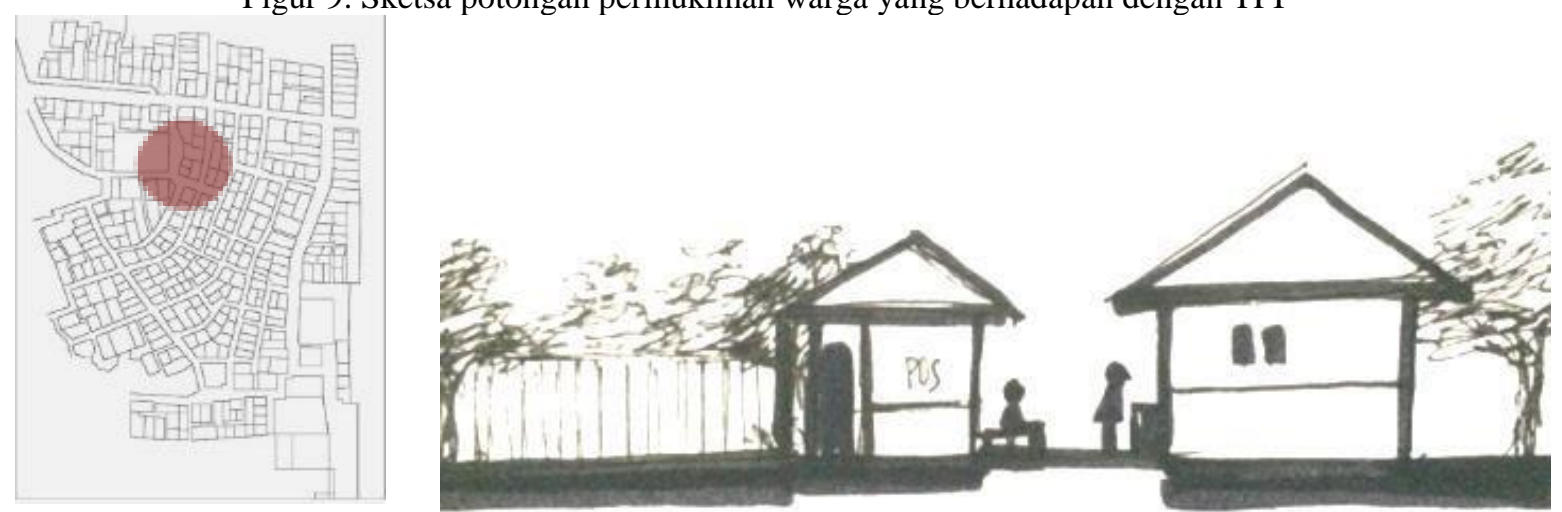

Figur 10. Sketsa potongan permukiman warga yang berhadapan dengan lapangan
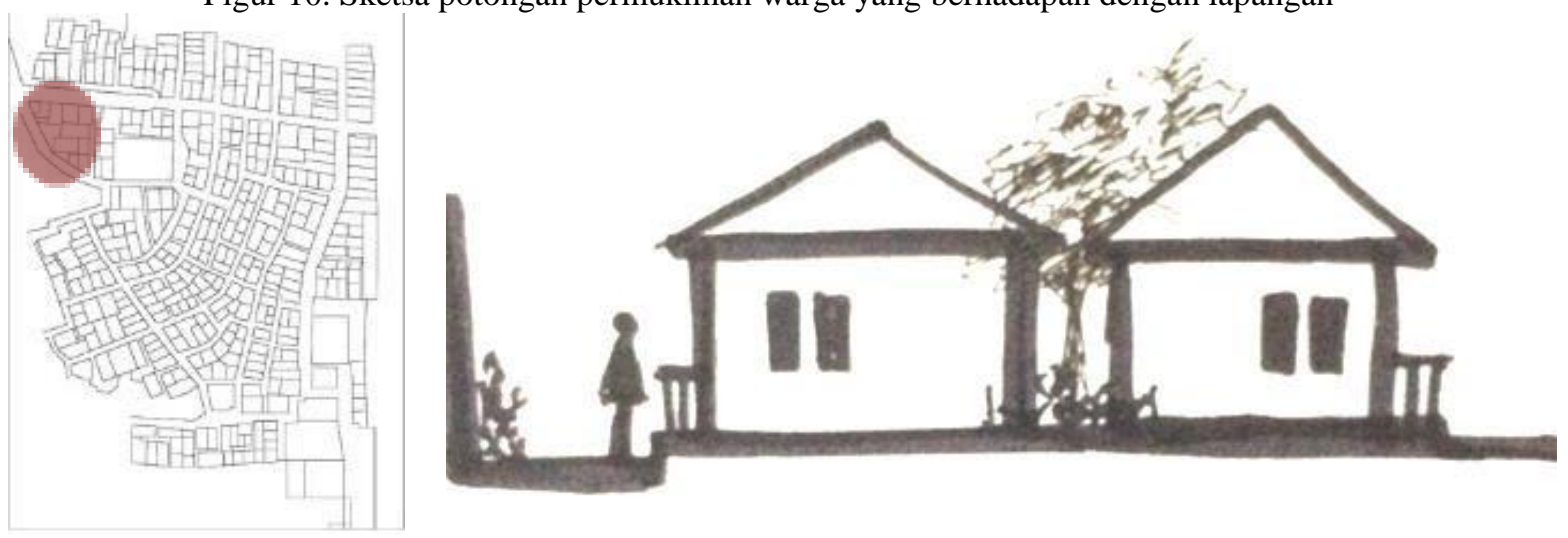

Figur 11. Sketsa potongan permukiman warga menghadap tempbok pembatas 


\section{Rumah menghadap rumah lain}

Sebagian besar rumah yang ada di permukiman nelayan Cilincing memiliki tipe rumah yang saling berhadap- hadapan satu sama lain. Tipe rumah yang seperti ini membuat hubungan kedekatan antara penghuni rumah (tetangga). Ruang jalan berada di antara dua rumah yang sebagian besar tidak memiliki teras. Sehingga kegiatan interaksi sosial banyak terjadi di depan rumah dan di tepi jalan. Rumah yang saling berhadapan menjadi elemen pelingkup bagi ruang luar jalan.

\section{Rumah menghadap Tempat pelelangan}

Rumah yang menggadap tempat pelelangan berada pada sirkulasi jalan utama kampong. Rumah yang menghadap TPI merupakan rumah 1 lantai yang memiliki teras di depan rumah dan banyak ditanami penghijauan baik pepohonanmaupun tanaman hias.

\section{Rumah menghadap sisi lapangan}

Lapangan olah raga yang berada ditengah- tengah permukiman warga dikelilingi oleh rumah- rumah berlantai satu. Rumah - rumah memiliki teras di depan rumah sebagai tempat untuk dan melakukan interaksi sosial. Di tepi lapangan terdapat kursi untuk tempat ibu- ibu bercengkrama. Rumah yang saling berhadap- hadapan memiliki pebagian ruang dimana ruang publik berada di depan rumah.

\section{Rumah menghadap tembok pembatas}

Beberapa rumah yang ada, menghadap kea rah dinding pembatas antara RT12 dengan RT 11. Rumah yang menghadap kearah dinding pembatas tidak memiliki teras untuk menerima tamu ataupun melakukan aktivitas lainnya.

(2) Tempat Pelelangan Ikan menjadi salah satu pusat aktivitas masyarakat 25ampong nelayan yang memiliki mata pencaharian utama sebagai nelayan. Di tempat pelelangan ikan ini biasanya akan di jumpai kegiatan jual-beli hasil laut.

(3) Musholla Musholla merupakan massa bangunan pada 25ampong yang dibangun untuk memenuhi kebutuhan rohani warga 25ampong nelayan Cilincing. Musholla memiliki letak yang berhadapan langsung dengan rumah warga. Antara musholla dengan rumah warga hanya dibatasi oleh jalan yang tidak begitu lebar hanya sekitar 1.5 meter.

Warung Warung merupakan wadah berkumpul warga

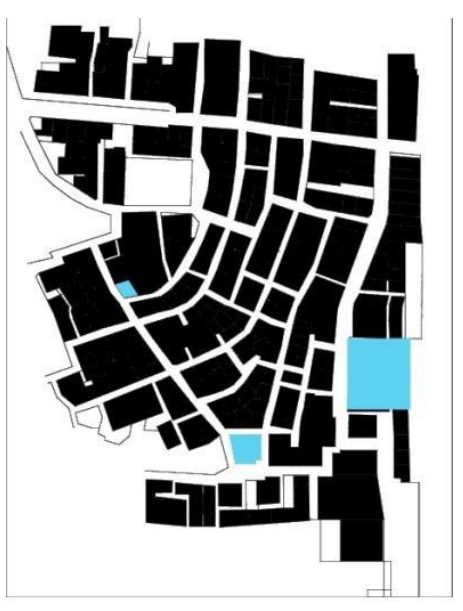

Figur 12.

RT12 terutama untuk para ibu- ibu. Warung yang ada di RT 12 berjumlah cukup banyak yaitu sekitar 5-8 buah warung yang tersebar merata diseluru sisi kmpung nelayan. Warung menjadi tempat interaksi social antar warga 25ampong nelayan selain di depan rumah.

\section{Ruang Terbuka (void) pada Kawasan Kampung}

(1) Ruang jalan pada kampung nelayan Cilincing baik jalan utama maupun jalan sekunder keduanya berupa koridor- koridor/ gang- gang sempit Ruang jalan pada kampung nelayan Cilincing memiliki pola campuran, yang didominasi oleh pola tertutup. 
(2) Lapangan pada kampung nelayan Cilincing menjadi penting karena lapangan dapat digunakan sebagai tempat untuk melakukan aktifitas sosial dan kebersamaan oleh warga setempat. Lapangan terletak pada area permukiman sehingga mudah untuk di akses oleh warga dan anak-anak yang ingin menggunakan lapangan tersebut. Lapangan berukuran cukup luas mampu menampung berbagai aktivitas.

(3) AreaPenjemuran Ikan. Menjemur ikan menjadi rutinitas yang selalu di lakukan oleh warga kampung nelayan. Ikan- ikan yang di peroleh dari hasil melaut tersebut dijemur agar dapat dijual menjadi ikan asin yang sangat di gemari oleh semua orang. Tempat menjemur ikan berada tidak jauh dari pelabuhan kapal nelayan dan juga tidak jauh dari permukiman warga.

(4) Area pelabuhan kapal menjadi tempat yang paling menarik karena disanalah terdampar banyak kapal- kapal nelayan dengan beragam warna dan ukuran. Area pelabuhan

kapal pada kampung nelayan Cilincing berada tepat di depan

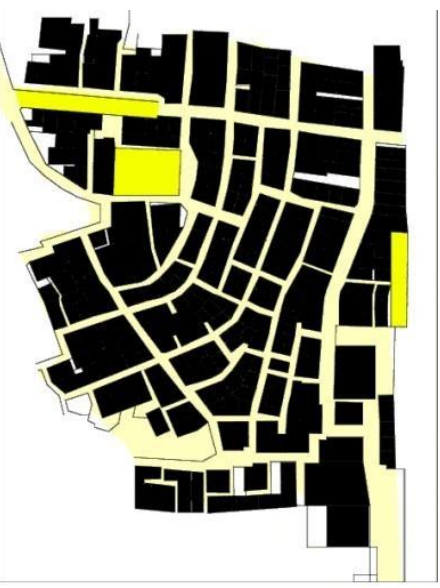
permukiman warga dan berada pada akses utama menuju Figur 13. permukiman dari jalan utama. Area pelabuhan kapal tidak hanya digunakan oleh nelayan saat mereka hendak melaut dan menurunkan hasil laut saja, namun sepanjang hari banyak nelayan yang gemar untuk tetap berada di atas kapal mereka.

Peta persebaran aktivitas berdasarkan gender pengguna ruang dari pagi hingga sore hari pada kampung nelayan Cilincing.
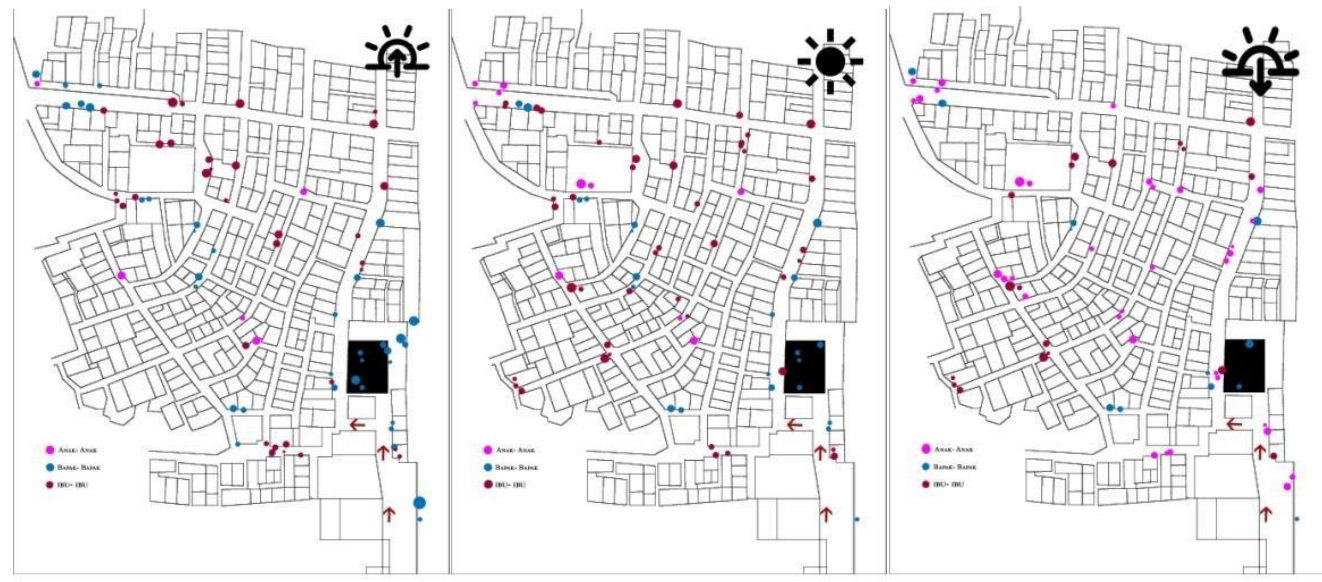

Figur 14.

\section{Karakter ruang pada kampung nelayan Cilincing}

Kampung nelayan Cilincing memiliki beberapa jenis Ruang berdasarkan intensitas, kompleksitas dan durasi kehadiran ruang tersebut.

Ruang Bersama Mikro

Ruang bersama skala mikro merupakan ruang yang memiliki kemajemukan paling sedikit dengan intensitas yang tinggi. Tempat yang dimanfaatkan adalah berupa pelataran yang dikarenakan tidak sedikit warganya tidak memilik ruang tamu, sehingga pelatan (atau teras) dan gang lah sebagai area perluasan pemanfaatan ruang, aktivitas dilakukan kebanyakan hanya dilakukan pada pagi dan siang hari.

Ruang Bersama Messo 
Ruang bersama kategori Messo merupakan ruang bersama dalam skala antar-kelompok warga, satu atau antar RT. Skala waktu dalam pemanfaatan ruang yaitu harian, mingguan dan bulanan. Tempat yang sering dimanfaatkan sebagai ruang bersama antara lain teras rumah, warung, teras mushola. Kegiatan yang dilakukan seperti arisan, ngobrol, dan rapat.

(3) Ruang Bersama Makro

Aktivitas bersama rutin mingguan, bulanan dan tahunan cenderung memanfaatkan ruang kampung nelayan makro. Aktivitas bersama rutin yang diselenggarakan mingguan yaitu pengajian untuk perempuan, laki-laki dan anak-anak. Tempatnya kegiatan dilakukan secara bergiliran antar peserta. Aktivitas bulanan, antara lain Posyandu. Kegiatan Posyandu biasanya dilakukan pada PAUD.

Kegiatan tahunan, berkaitan dengan hari raya agama Islam. Ruang bersama yang terjadi adalah di area Musholah, ruang bersama saat bersilaturakhmi, yaitu jalan, pelataran, teras (emper), dan ruang bersama saat penyembelihan hewan qurban bertempat di lapangan sepak bola.

\subsubsection{Kampung nelayan Marunda}

Kampung memiliki konfigurasi tatanan massa yang bersifat heterogen, susunan kawasan yang memiliki dua atau lebih pola berbenturan. 70\% dari total luas kampung nelayan Marunda merupakan ruang terbuka yang berbentuk empang. Ruang- ruang luar yang terbentuk pun sebagain besar bukan berupakan lived spaced, karena masyarakat enggan menggunakan ruang tersebut untuk kegiatan sehari- hari.

Berdasarkan teori Rapoport (1977), kampung nelayan Marunda tergolong kedalam tatanan kampung yang memiliki orientasi permukiman menyusuri jalan/ along the streets. Ada dua macam organisasi dalam orientasi permukiman tersebut, yaitu rumah berada di sepanjang jalan dan berseberangan dengan rumah lain atau rumah berada disepanjang jalan dan berseberangan dengan unsur air (waterfront), dalam kampung nelayan Marunda yaitu empang.

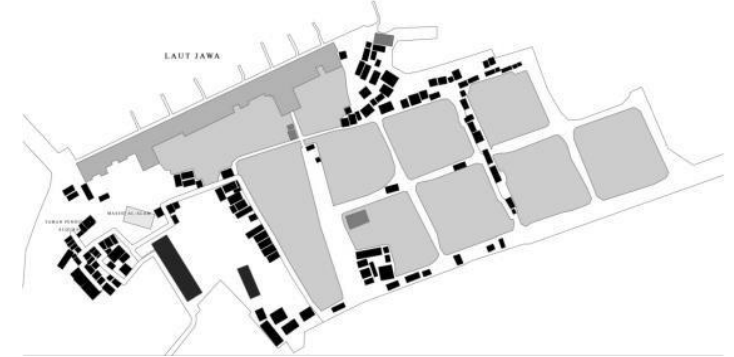

Figur 15. Ground kampung nelayan Marunda

Konfigurasi tata massa kampung tersebut membentuk pola- pola penempatan massa yang beragam. Masyarakat pun membangun rumah mereka mulai dari tepi pantai hingga daratan. Sehingga muncul tiga tipe rumah pada kampung nelayan Marunda, diantaranya:

\section{Rumah panggung di tepian air}

Permukiman yang berada di transisi antara darat dan lau tersebut membuat daratan kampung sangat terbatas sehingga warga cenderung meng-expand (memperluas) rumah mereka kearah laut dan membuat sturktur penopang dalam air sehinga rumah yang tercipta adalah rumah berbentuk panggung. Rumah tepian air memiliki tampak muka bangunan menghadap jalan dan tampak belakang rumah menghadap laut, sungai, dan juga empang 


\section{Rumah panggung di darat}

Rumah panggung di darat pada kampung nelayan Marunda digunakan warga sebagai tempat untuk menyimpan peralatan rumah tangga atauoun digunakan sebagai kandang hewan. Rumah panggung pun dibuat warga untuk menghindari terjadinya banjir ketika air laut sedang pasang. Jalan yang berada di depan ruamh menjadi pembatas antara rumah dengan empang.

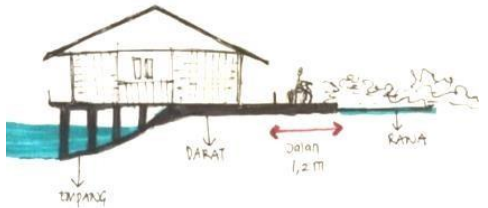

Figur 16. Rumah Panggung di Tepian Air

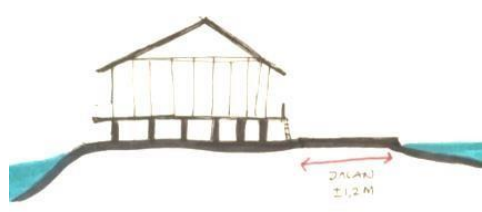

Figur 17. Rumah Panggung Darat

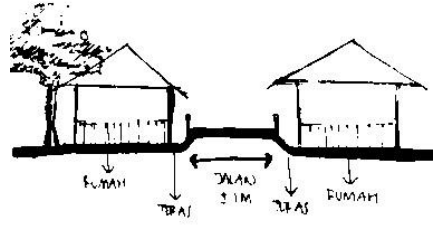

Figur 18. Rumah di Darat

\section{Rumah di darat}

Kampung nelayan Marunda memiliki konfigurasi tata massa yang bersifat menyebar dan berantakan membagi kampung tersebut menjadi beberapa bagian daratan ada yang berbentuk linier memanjang ada juga yang berupa daratan cukup luas berbentuk organik.

Aktivitas masyarakat nelayan Marunda cenderung memusat pada ruang- ruang luar yang bersifat pasti dalam pengertian memiliki luas dan tingkat kenyamanan yang cukup untuk melakukan aktivitas mereka sehari- hari baik melaut maupun bermukim. Bapak- bapak melakukan aktivitas keseharian pada tempat- tempat yang mampu menampung kegiatan seeperti memancing, membuat jala, dan sebagainya. Berikut adalah analisa aktivitas utama masyarakat kampung nelayan Marunda, diantaranya:

Tabel 1. Hubungan Aktivitas Masyarakat Nelayan Dengan Dengan Ruang Luar Kampung Nelayan Marunda Sumber: Penelitian, 2016

\begin{tabular}{|c|c|c|c|c|c|}
\hline $\begin{array}{c}\text { Permukiman } \\
\text { Nelayan }\end{array}$ & $\begin{array}{c}\text { Aktivitas } \\
\text { Bermukim }\end{array}$ & $\begin{array}{c}\text { Aktivitas } \\
\text { Melaut }\end{array}$ & $\begin{array}{l}\text { Aktivitas } \\
\text { menjemur } \\
\text { ikan }\end{array}$ & $\begin{array}{c}\text { Aktivitas } \\
\text { berdagang }\end{array}$ & $\begin{array}{c}\text { Aktivitas } \\
\text { mengupas } \\
\text { kerang dan } \\
\text { udang }\end{array}$ \\
\hline $\begin{array}{l}\text { Kampung } \\
\text { nelayan } \\
\text { Marunda }\end{array}$ & $\begin{array}{l}\text { Tata massa yang } \\
\text { linier mengikuti } \\
\text { pola sirkulasi } \\
\text { jalan. } \\
\text { Cenderung } \\
\text { menyebar } \\
\text { dengan sebagian } \\
\text { besar massa } \\
\text { yang terbangun } \\
\text { menghadap } \\
\text { empang. }\end{array}$ & $\begin{array}{l}\text { jarak yang } \\
\text { ditempuh dari } \\
\text { permukiman } \\
\text { menuju area } \\
\text { pelabuhan kapal } \\
\text { dalam kurun } \\
\text { waktu 5-10 } \\
\text { menit dengan } \\
\text { berjalan kaki. }\end{array}$ & $\begin{array}{l}\text { mejemur } \\
\text { ikan } \\
\text { dilakukan di } \\
\text { area depa } \\
\text { n rumah } \\
\text { masing- } \\
\text { masing } \\
\text { warga. Tidak } \\
\text { semua warga } \\
\text { melakukan } \\
\text { aktivitas } \\
\text { menjemur } \\
\text { ikan. }\end{array}$ & $\begin{array}{l}\text { Aktivitas } \\
\text { jual- beli } \\
\text { hasil laut } \\
\text { dilakukan di } \\
\text { zona industri } \\
\text { kelautan. }\end{array}$ & 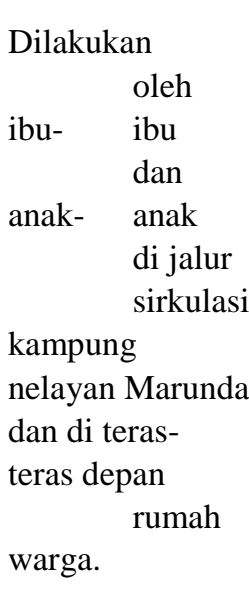 \\
\hline
\end{tabular}




\section{Tata Massa Kampung Nelayan Marunda (Solid-Void Kawasan)}

Konfigurasi tatanan massa pada kampung nelayan Marunda membentuk banyak voidvoid kawasan seperti empang, jalan yang cukup luas, dan ruang- ruang terbuka lainnya. Pola tatanan menyebar menciptakan banyak ruang- ruang kosong yang tidak dapat digunakan.

\section{(1) Massa (solid) pada kawasan kampung}

\section{Permukiman Nelayan}

Kampung nelayan Marunda memiliki konfigurasi tatanan massa yang bersifat heterogen, susunan kawasan yang memiliki dua atau lebih pola berbenturan. $70 \%$ dari total luas kampung nelayan Marunda merupakan ruang terbuka yang berbentuk empang. Daratan yang terbentuk cenderung berbentuk linier dan berupa jalan setapak. Ruang- ruang luar yang terbentuk sebagian

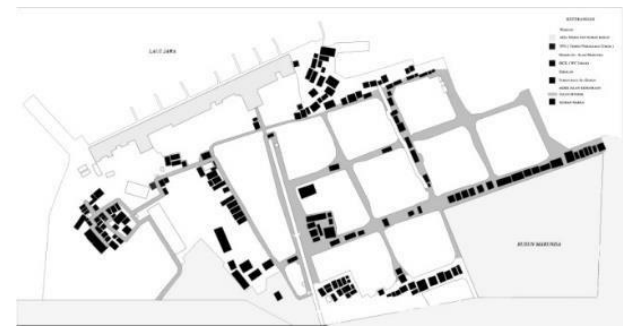

Figur 19. besar bukan berupakan lived spaced, karena jarang didgunakan untuk kegiatan sehari- hari.

Ada dua macam organisasi dalam orientasi permukiman tersebut, yaitu rumah berada di sepanjang jalan dan berseberangan dengan rumah lain atau rumah berada disepanjang jalan dan berseberangan dengan unsur air (waterfront), dalam kampung nelayan Marunda yaitu empang. Konfigurasi tata massa kampung tersebut membentuk pola- pola penempatan massa yang beragam. Masyarakat pun membangun rumah mereka mulai dari tepi pantai hingga daratan. Sehingga muncul tiga tipe rumah pada kampung nelayan Marunda, diantaranya:

\section{a. Rumah panggung di tepian air}

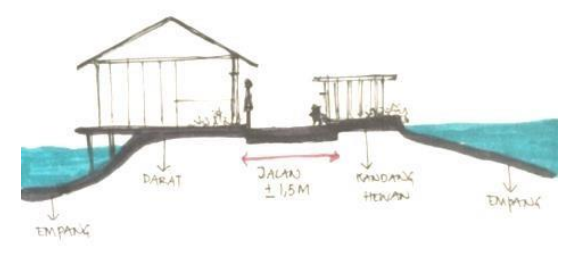

\section{b. Rumah panggung di darat}

\section{c. Rumah di darat}
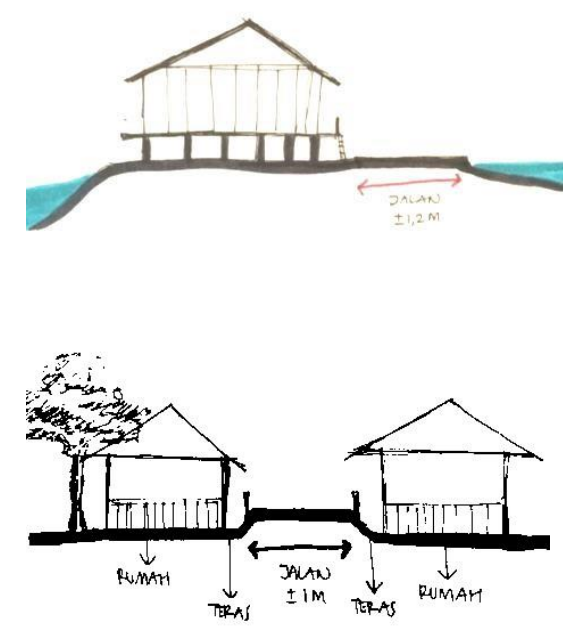

Figur 20. 


\section{Peta persebaran aktivitas masyarakat kampung nelayan Marunda}

Setelah di analisa berdasarkan gender pengguna ruang maka di dapat peta persebaran aktivitas warga kampung nelayan Marunda dari pagi hingga sore hari. Penggunaan ruang untuk aktivitas bermukim dan melaut lebih bersifat memusat pada waktu- waktu yang berbeda.

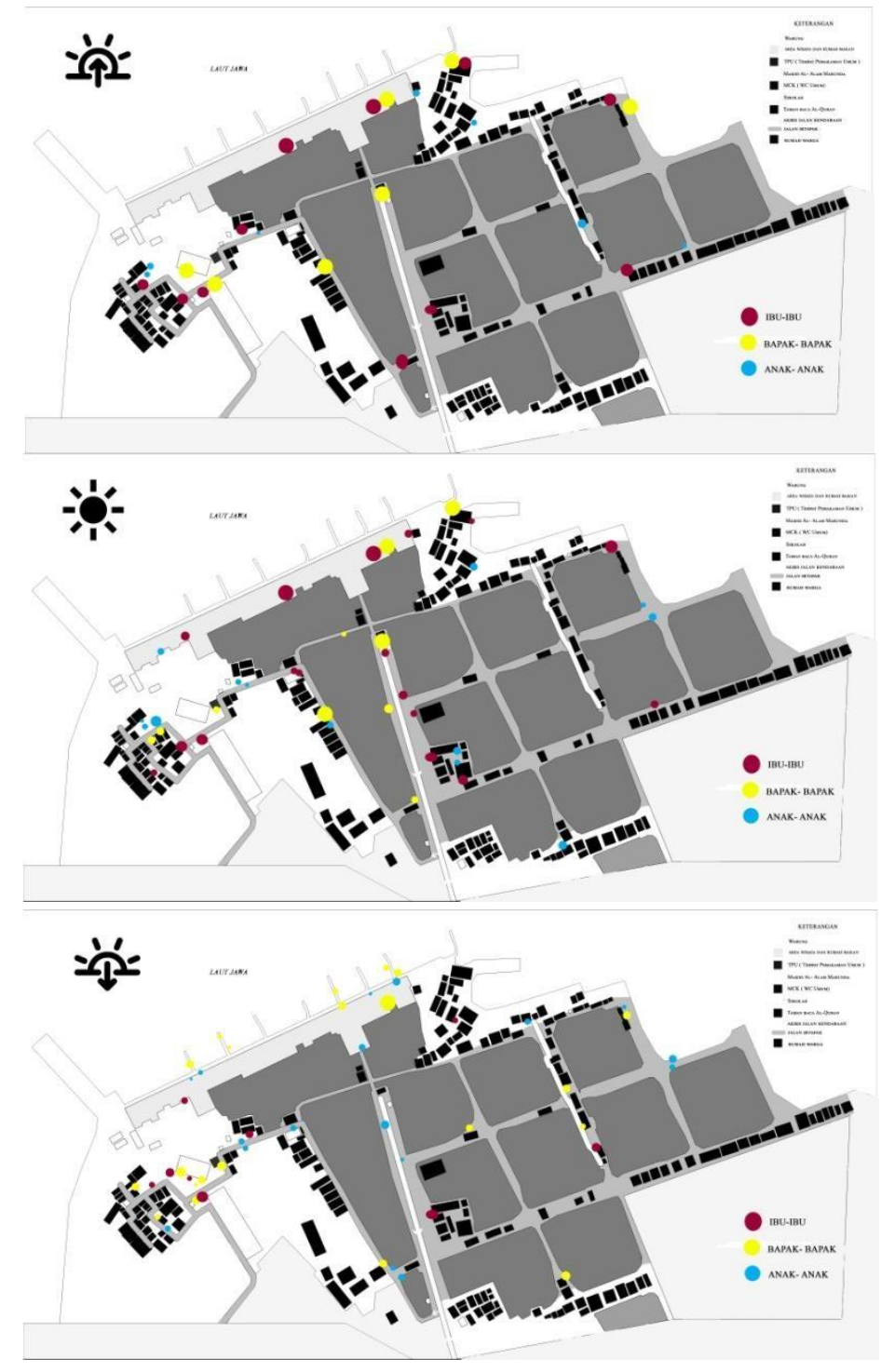

Figur 21.

\subsection{SINTESA KETERKAITAN TATA MASSA DENGAN AKTIVITAS PADA RUANG LUAR KAMPUNG NELAYAN}

Aktivitas melaut yang dilakukan oleh masyarakat nelayan membutuhkan sarana aktivitas berupa tempat dermaga kapal, pasar ikan, area penjemuran, dan area pembuatan logistik melaut. Dari tabel dibawah maka dapat diketahui apakah sarana sarnan tersebut digunakan secara maksimal oleh warga kampung nelayan Cilincing dan Marunda. 
Tabel 2. Keterkaitan tata massa dengan aktivitas pada ruang luar kampung nelayan Cilincing Sumber: Hasil Pengamatan, 2016

\begin{tabular}{|l|l|l|}
\hline \multicolumn{1}{|c|}{ Sarana Kebutuhan Melaut } & \multicolumn{1}{|c|}{$\begin{array}{c}\text { Lokasi Sarana Kebutuhan } \\
\text { Melaut }\end{array}$} & \multicolumn{1}{c|}{ Keterangan } \\
\hline 1. Tempat Dermaga Kapal & $\begin{array}{l}\text { Dermaga kapal berada dekat } \\
\text { dengan permukiman warga dan } \\
\text { dengan pasar ikan. }\end{array}$ & $\begin{array}{l}\text { Memiliki luas yang cukup untuk } \\
\text { menampung kapal- kapal } \\
\text { nelayan yang bersandar }\end{array}$ \\
\hline 2. Tempat penjemuran ikan & $\begin{array}{l}\text { Area penjemuran berada di satu } \\
\text { titik bersebelahan dengan tempat } \\
\text { pelelangan ikan (pasar ikan) } \\
\text { sehingga mobilisasi pengangkutan } \\
\text { ikan menjadi mudah }\end{array}$ & $\begin{array}{l}\text { Tempat penjemuran tidak begitu } \\
\text { luas namun cukup untuk } \\
\text { melakukan penjemuran ikan } \\
\text { secara bersamaan. Berada di tepi } \\
\text { laut yang terkena sinar matahari } \\
\text { langsung. }\end{array}$ \\
\hline 3. Tempat Perdagangan Ikan & $\begin{array}{l}\text { Berada diantara permukiman dan } \\
\text { laut. Jarak tempuh yang dekat } \\
\text { antara pasar dengan permukiman } \\
\text { dan pasar dengan dermaga. }\end{array}$ & $\begin{array}{l}\text { Cukup luas untuk menampung } \\
\text { hasil laut, berupa massa yang } \\
\text { ternaungi atap namun tidak ada } \\
\text { pembatas yang tertutup. } \\
\text { Sehingga sirkulasi udara dan } \\
\text { pencahayaan menjadi maksimal } \\
\text { di dalam pasar ikan. }\end{array}$ \\
\hline $\begin{array}{l}\text { 4. Tempat pembuatan logistik } \\
\text { melaut }\end{array}$ & $\begin{array}{l}\text { Pembuatan logistik dilakukan di } \\
\text { teras- teras depan rumah warga dan } \\
\text { di dermaga kapal. }\end{array}$ & $\begin{array}{l}\text { Dilakukan pada bulan- bulan } \\
\text { nelayan sedang tidak melaut. Di } \\
\text { buat bersama- sama oleh } \\
\text { beberapa warga di ruang luar. }\end{array}$ \\
\hline
\end{tabular}

Tabel 6.2 Keterkaitan tata massa dengan aktivitas pada ruang luar kampung nelayan Marunda Sumber: Hasil Pengamatan, 2016

\begin{tabular}{|l|l|l|}
\hline \multicolumn{1}{|c|}{ Sarana Kebutuhan Melaut } & \multicolumn{1}{|c|}{$\begin{array}{c}\text { Lokasi Sarana Kebutuhan } \\
\text { Melaut }\end{array}$} & \multicolumn{1}{c|}{ Keterangan } \\
\hline 1. Tempat Dermaga Kapal & $\begin{array}{l}\text { Dermaga kapal berada dekat / tepi } \\
\text { laut namun jauh dari permukiman } \\
\text { warga. }\end{array}$ & $\begin{array}{l}\text { Berada di tepi laut cukup luas } \\
\text { untuk menampung kapal- kapal } \\
\text { nelayan yang berlabuh. Di hari- } \\
\text { hari libur ramai dipadati } \\
\text { wisatawan yang ingin } \\
\text { berkeliling pantai dengan perahu } \\
\text { nelayan. }\end{array}$ \\
\hline 2. Tempat penjemuran ikan & $\begin{array}{l}\text { Penjemuran ikan dilakukan di } \\
\text { depan rumah masing- masing warga } \\
\text { yang melakukan kegiatan tersebut. }\end{array}$ & $\begin{array}{l}\text { Berupa ruang luar yang tidak } \\
\text { ternaungi, sehingga } \\
\text { mendapatkan sinar matahari } \\
\text { langsung dan hawa amis dapat } \\
\text { ternetralisir oleh penghawaan } \\
\text { alami. }\end{array}$ \\
\hline 3. Tempat Perdagangan Ikan & $\begin{array}{l}\text { Berada dekat dengan dermaga kapal } \\
\text { namun cukup jauh dari } \\
\text { permukiman. }\end{array}$ & $\begin{array}{l}\text { Berbentuk massa yang teratapi, } \\
\text { pencahayaan kurang maksimal } \\
\text { di dalam pasar ikan. }\end{array}$ \\
\hline
\end{tabular}


4. Tempat pembuatan logistik melaut
Tidak terlihat adanya tempat

membuat logistik melaut. Pada

umumnya nelayan memperoleh dari

kampung nelayan Cilincing.

\subsection{PERSAMAAN KAMPUNG NELAYAN CILINCING DAN MARUNDA}

Kedua objek pengamatan memiliki persamaan dalam beberapa hal, seperti:

\section{Lokasi}

Kedua kampung nelayan sama-sama merupakan permukiman nelayan yang berada di tepian aur (laut). Keduanya merupakan permukiman yang menjadi transisi antara daratan dan lautan. Laut jawa menjadi garis pembatas di sebelah utara- timur kampung nelayan Cilincing dan kampung nelayan Marunda.

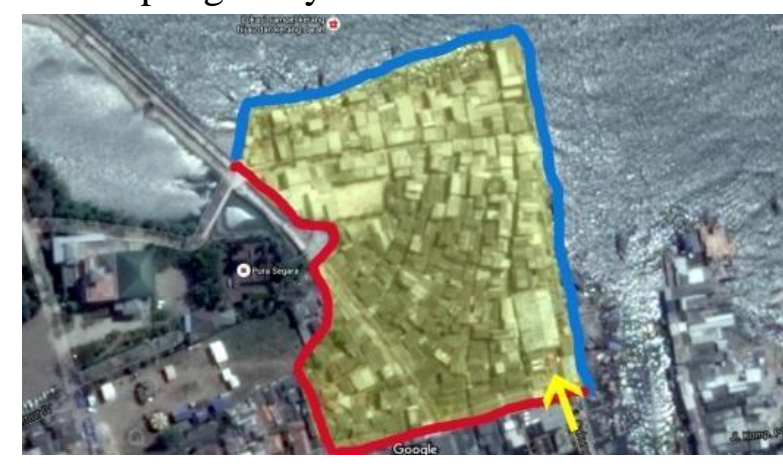

Figur 22. Kampung Nelayan Cilincing

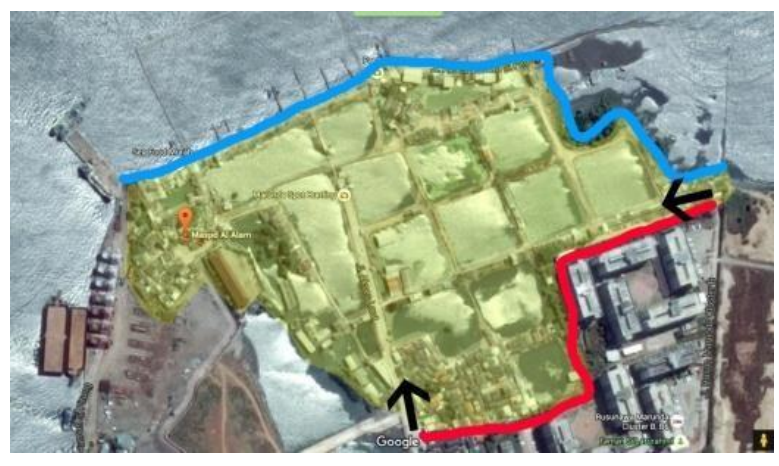

Figur 23. Kampung Nelayan Marunda

\section{Aktivitas}

Aktivitas yang terjadi pada kedua kampung nelayan (Cilincing dan Marunda) memiliki kesaaman. Kedua kampung tersebut memiliki warga yang sebagian besar bermata pencaharian sebagai nelayan. Bapak- bapak sebagian besar menjadi nelayan dan ibu- ibu membantu mengeringkan ikan, mengupas hasil laut, dan melakukan pekerjaan rumah tangga lain. Sedangkan warga lain yang tidak berprofesi sebagai nelayan bekerja menjadi kuli, pedagang, dan buruh pabri.

\subsection{PERBEDAAN KAMPUNG NELAYAN CILINCING DAN MARUNDA}

Selain persamaan yang dimiliki kedua kampung, terdapat juga perbedaan yang membedakan kedua kampung nelayan tersebut secara mendasar, diantaranya:

(1) Tata Massa

Kampung nelayan Cilincing dan Marunda memiliki perbedaan tata massa yang cukup signifikan. Kampung nelayan Cilincing memiliki tata massa yang cenderung rapat dan padat. Jumlah penduduk di kampung nelayan Cilincing yang berjumlah lebih banyak dari pada kampung nelayan Marunda. Kampung nelayan Marunda didominasi oleh empang membuat tata massa pada kampung menjadi lebih renggang- renggang dan menyebar.

\section{(2) Pemanfaatan Ruang Luar}

Kedua kampung nelayan yakni kampung nelayan Cilincing dan marunda memiliki aktivitas pada ruang luar yang hampir serupa karena berlatar belakang penduduk dominan adalah nelayan. Kampung nelayan marunda memiliki kecenderungan membentuk ruang luar yang bersifat negatif sehingga intensitas penggunaan ruang luar pada kampung nelayan Marunda lebih rendah jika di bandingkan dengan kampung nelayan Cilincing. 


\section{KESIMPULAN}

\subsection{KESIMPULAN}

Setiap kampung memiliki ciri khas nya masing-masing, terutama kampung nelayan. Kampung nelayan merupakan permukiman yang berada di antara air dan daratan tersebut memiliki ruang luar yang terbentuk dari konfigurasi tata massa kampung. Tata massa setiap kampung berbeda-beda. Hal ini mengakibatkan adanya perbedaan respon dari tiap- tiap warga kampung untuk memafaatkan ruang luar yang ada sebagai wadah untuk melakukan aktivitas mereka sehari- hari. Aktivitas yang di teliti antara lain aktivitas melaut dan bermukim warga kampung nelayan Cilincing dan Marunda.

Kampung nelayan Cilingcing memiliki bentuk tata massa yang bersifat homogen dengan orientasi ke dalam (inside-out). Massa-massa yang ada saling berhadapan dan membentuk jaringan sirkulasi jalan utama dan sekunder yang berbentuk koridor atau ganggang sempit. Tata massa pada kampung nelayan Cilincing berpotensi membentuk ruang luar yang menjadi ruang sosial, warga mejadi nyaman untuk beraktivitas dan berinteraksi dengan tetangganya. Intensitas penggunaan ruang- ruang tersebut cukup tinggi karena digunakan setiap hari dan dalam periode waktu yang cukup lama. Penggunaan ruang oleh warga di dominasi oleh orang dewasa baik pria maupun wanita.

Kampung nelayan Marunda memiliki konfigurasi tata massa yang bersifat heterogen. Dimana terdapat dua jenis tata massa pada kampung tersebut. Kampung memiliki orientasi permukiman yang sebagian besar menyusuri jalan atau empang. Rumah- rumah dan bangunan yang ada memiliki dua wajah dan tidak saling berhadapan. Namun sebagian permukiman saling berhadapan dan berdekatan di sisi lain kampung. sehingga pola tata massa keseluruhan kampung terlihat berantakan dan menyebar. 70\% bagian kampung nelayan Marunda berupa empang dan rawa. Ruang luar kampung tidak dapat menjadi wadah bagi warga untuk melakukan interaksi sosial, interaksi sosial hanya terjadi di area warung dan Masjid dengan intensitas rendah. Ruang luar yang ada cenderung lebih menarik wisatawan atau masyarakat dari luar kampung sendiri.

Konfigurasi tata massa yang berbeda pada kedua kampung nelayan yang memiliki aktivitas yang hampir sama memiliki pengaruh pada intensitas pemanfaatan ruang luar yang terbentuk pada masing- masing kampung. Konfigurasi tata massa kampung yang bersifat homogen membentuk ruang luar yang memiliki kedekatan yang cukup tinggi. Hal ini menyebabkan intensitas pemanfaatan ruang luar menjadi tinggi, karena ruang luar menjadi wadah bagi warga kampung untuk melakukan aktivitas dan melakukan interaksi sosial.

\subsection{SARAN}

Pola penataan kawasan kampung perlu memperhatikan pola aktivitas permukiman yang sebagian besar di lakukan pada ruang luar. Pada lingkup penelitian ini ditinjau konfigurasi tata massa kampung dan pola aktivitas masyarakat nelayan yang mendiami permukiman tepi laut kebutuhan akan ruang luar dalam menunjang aktivvitas utama masyaraka, yaitu melaut harus dapat terfasilitasi dengan baik. Sehingga masyarakat dapat bermukim dengan layak dan dapat melakukan aktivitas sehari- hari dengan layak. 


\section{DAFTAR PUSTAKA}

Adhy Setiawan, Eko. (2004). "Gambaran Tentang Ruang Luar Kampung Nelayan Betawi Pesisir di Marunda Pulo dan Upaya Peningkatan Nilai Ekonomis”. Penelitian Unggulan Terpadu VI, Lembaga Penelitian, Uniersitas Trisakti

Altman, I. (1975). The Environment and Social Behavior. Monterey, CA: Wadsworth.

Carr dan Rekan. (1992). Public Space. New York: Cambridge University Press.

Carswell, Bill. (1987). Architecture 765 Theory of Urban Design. Professor Publishing. Hauge, Ashild Lappegard. (2007). "Identity and Place: a critical comparison of three identity theories". Architectural Science Review

Idawarni. (2013). "Kaitan Pekerjaan dengan Permukiman Nelayan". Temu Ilmiah IPLBI, Lab. Permukiman dan Perumahan, Program Studi Arsitektur, Departemen Arsitektur, Fakultas Teknik, Universitas Hasanuddin

Kurniawan, Kukuh Alfandhi. (2011). "Sistem Seting dan Sistem Aktivitas pada Kampung Nelayan Tambakrejo (tamban) Kabupaten Malang.". Fakultas Teknik Jurusan Arsitektur Universitas Brawijaya.

Kusnadi. (2000). Nelayan: Strategi Adaptasi dan Jaringan Sosial. Humaniora Utama Press. Bandung Listianty, Serly. (2011). "Transformasi Rumah Panggung Pada Permukiman Pesisir Jakarta Utara". Jurnal Skripsi Falkutas Teknik Universitas Indonesia.

Lynch, Kevin. (1981). Good City Form. Massachusetts: MIT Press.

Najafi Mina, Mustafa Kamal Bin Mohd Shariff. 2011. The Concept of Place and Sense of Place in Architectural Studies. International Journal of Social, Behavioral, Educational, Economic, Business and Industrial Engineering, 5(8).

Nuryanto, Isep Machpudin. (2008). "Kajian Pola Kampung Dan Rumah Tinggal”. Artikel hasil penelitian arsitektur tradisional sunda.

Rapoport, Amos. (1977). Human aspect of Urban Form. Oxford, New York, Toronto, Sydney, Paris, Frankfurt: Pergamon Press.

Kadoatie, Robert J, Roestam Sjarief. (2010). Tata Ruang Air. Yogyakarta: Penerbit Andi.

Roji, Fatur. (2015). Masjid Al-Alam Marunda Tempat Si Pitung Bermain. [Online]. Tersedia: http://www.suaramasjid.com/read/masjid-al-alam-marunda-tempat-si-pitung-bermain/. $\quad[30$ Maret 2016].

Sajid, Syahmi. (2015). Pengertian, Fungsi, dan Manfaat Tempat Pelelangan Ikan (TPI). [online]. Tersedia: http://ipsgampang.blogspot.co.id/2015/01/fungsi-dan-manfaattempatpelelangan.html/. [ 25 februari 2016].

Trancik, Roger. Finding Lost Space, Van Nostrand: New York, 1986. Chapter 4: The Theories of Urban Spatial Design. p 97-124. 2009. Keberdayaan Nelayan dan Dinamika Ekonomi Pesisir. Yogyakarta: Ar-Ruzz Media.

Widyanto, Untung; Yuliastuti, Dian. (2011). Perempuan Perkasa di Pusaran Iklim. [Online]. Tersedia: https://nasional.tempo.co/read/news/2011/03/30/173323808/perempuan-perkasa-dipusaraniklim. [28 Februari 2016]. 